\title{
FLOWSHEET ASSESSMENT AND CAPACITY EVALUATION OF AN IRON ORE PROCESSING PLANT BY SIMULATION
}

\author{
Baran Tufan
}

Original scientific paper

An iron ore processing plant in Sivas (Turkey) was investigated and simulated depending on real and experimental data in this study. The AggFlow ${ }^{\mathrm{TM}}$ simulation packaged program was used and the experimental results conducted in mineral processing laboratories of Dokuz Eylül University were applied to the simulation when necessary. The results gathered by AggFlow were crosschecked with experimental and real data. The former plant design observations, experimental results and simulation software were combined to present an optimum plant design by calculating the final concentrate outputs. Hence, the simulation not only helped in machinery and equipment selection, but also put forth some economic aspects before the assembly of the plant. The importance of simulation was revealed since the company owners would be aware of the amount of capital investment, production costs, and the machinery to be ordered and most importantly, the amount of concentrate to be produced with different alternatives and applications.

Keywords: flowsheet assessment; iron; mineral processing plant; simulation

Procjena dijagrama toka procesa i evaluacija kapaciteta pogona za obradu željezne rudače simulacijom

Izvorni znanstveni članak Ispitivao se i simulirao pogon za obradu željezne rudače u Sivasu (Turska) na temelju stvarnih i eksperimentalnih rezultata. Primijenjen je AggFlow ${ }^{\mathrm{TM}}$ simulacijski program, a prema potrebi koristili su se eksperimentalni rezultati dobiveni u laboratorijima za obradu metala Dokuz Eylül Univerziteta. Rezultati dobiveni AggFlow ${ }^{\mathrm{TM}}$ programom usporedili su se s eksperimentalnim i stvarnim podacima. Kombinirali su se postojeći podaci pogona, eksperimentalni rezultati i oni dobiveni simulacijskim programom kako bi se dobio optimalni projekt pogona s proračunom konačnih rezultata. Simulacija nije pomogla samo kod odabira strojeva i opreme već je istaknula neke ekonomske aspekte prije montiranja pogona. Pokazala se važnost simulacije jer bi tako vlasnici kompanije postali svjesni količine ulaganja kapitala, proizvodnih troškova i potrebnih strojeva, a što je najvažnije, količine koncentrata koja se može proizvesti raznim alternativama i primjenama

Ključneriječi: pogon za obradu minerala; procjena dijagrama toka procesa; simulacija; željezo

\section{Introduction}

The use of computer simulation technique in analyzing and designing mineral processing systems has become popular in last decades. The simulation of a system simply creates a representative model of the system itself. The procedure of simulation proceeds with evaluating different strategies that have positive effects on the system. Besides, simulation allows the revised system to be completed, to run trials and estimate the period of errors occurring with experimental studies $[1 \div 2]$. The simulation of a system is required when the system is not established yet, the experimentation in the system is dangerous and/or analytical solutions are insufficient or time taking [3]. The economic factors are also challenging factors in the decision of simulation applications.

The plant design concept involves all the engineering work to establish a new plant or to revise the existing plant in line with the requirements. From the technical point of view, the design concludes the fabrication of desired units or products by proposing the most suitable flowsheet and capacity with the required energy and mass balance. However, the plant design is not just a technical work, but also an industrial application to satisfy the economical expectations such as capital investment and production costs [4]. The flowsheet design is prior and significant in mineral processing plant designs. The selection of machinery and equipment should commence subsequently regarding model, required power and capacity [5].

In the last 30 years, the necessity of preparing alternative plant designs is revealed due to increasing demand, decreasing profit ratio for the companies, decreasing ore prices and increasing unit cost. The capacity of machinery increased simultaneously with the necessity of alternative plant design combinations [6]. Therefore, the electric consumption which is the main production cost of the plants is multiplied. The simulation and optimization of crushing and grinding equipment in the plants caused significant benefit in an economical way. The use of simulation software shortens the building of facilities and enhances the performance and efficiency [7]. However, the simulation packaged programs are regarded as insufficient in flotation, separation and grinding circuits. For this reason, even the most sophisticated simulation packaged program cannot achieve total design of a mineral processing plant as the user requested [8]. The data to be used in simulation should be well evaluated depending on experimental results and/or field surveys.

Simulation provides simplicity, lower capital and production cost, safety, solution to what-if scenarios, no harm to environment, controllability and time saving. The simulation may fail due to many reasons such as the budget is exceeded, deadline is passed, unnecessary details are given, wrong data is used, etc. $[9 \div 10]$.

The high potential of Turkey in mining industries has not been measured up to the desired point in spite of rapid growth in last years. Thus, application of new technologies should induce new expansions for a more active role in the industry [11]. Significant factors in the sector are the following: using suitable and right production technology, selecting suitable and economic machinery and equipment and providing sustainable production with required knowledge [12]. The insufficient knowledge of some company owners and processing plant 
managers causes an inefficient or under capacity production which yields high economic loss.

Hence, an iron ore processing plant in Sivas, Turkey was investigated and simulated depending on real and experimental data in this study. The AggFlow ${ }^{\mathrm{TM}}$ simulation packaged program was used since the software provided sufficient applications of material balance, flowsheet design and equipment selection with easy access. The experimental results conducted in mineral processing laboratories of Dokuz Eylül University were applied to the simulation when necessary. Several what-if scenarios were applied including capacity raise, different crusher type selection, different screen sizes, different separation sized cyclone applications, different sized products etc. This study concluded by determination of capacity suitability for an iron ore processing plant and suggestion of an optimum flowsheet design which is already applied and running in the related plant in Sivas, Turkey.

\section{Materials and Method}

The iron ore, extracted from an open pit mine in Taslitepe vicinity near Divrigi District in the city of Sivas, Turkey, was beneficiated in dry crushing-screening plant. There existed some difficulties such as low recovery rate, limited processing regarding size of the ore, harsh weather conditions and a non-beneficiated tailing dump of $800000 \mathrm{~m}^{3}$ with high Fe grade. The produced ore blocks from open pit mine (over $100 \mathrm{~mm}$ in size) were crushed by excavators fed into the washing plant [13]. In summary, the iron ore with a size of $+30 \mathrm{~mm}$ was triaged and fed to the crusher $(-30 \mathrm{~mm})$ to be fed to the magnetic separator subsequently. The beneficiated ore of $-30+10$ $\mathrm{mm}$ in size could be sold directly. The ore with the size of $-10+0,5 \mathrm{~mm}$ and $-0,5 \mathrm{~mm}$ was classified and $-10+0,5$ $\mathrm{mm}$ size fraction was stocked. The finer sized particles $(-0,5 \mathrm{~mm})$ were fed to slurry tanks and sedimented to recycle clean water, and besides the dried slurry could be sold as sand material. The investigations revealed that 23 $\%$ of the stocked $-10+0,5 \mathrm{~mm}$ sized particles were economical iron concentrates.

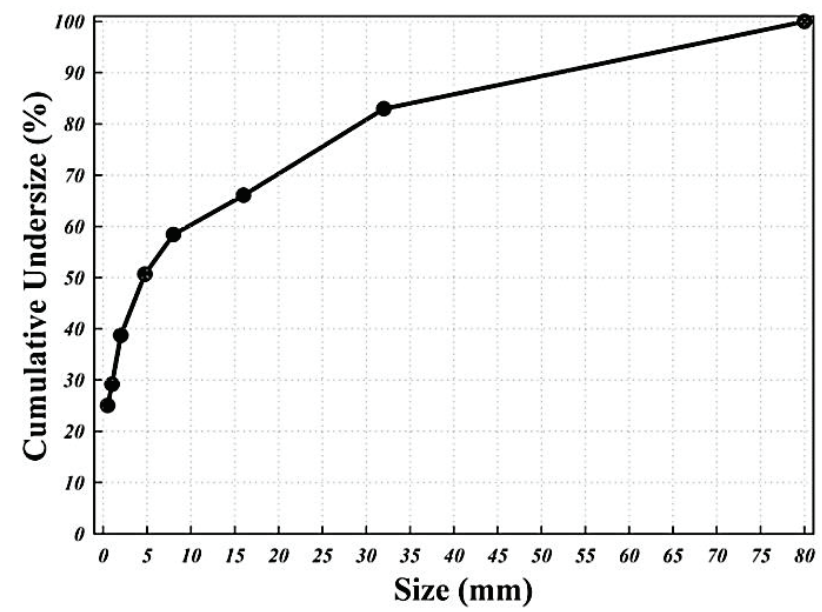

Figure 1 The undersize particle size distribution of the run of mine ore

The homogeneous pulp was analyzed and $25 \%$ of the sample was observed to be below $0,5 \mathrm{~mm}$ (see Fig. 1). The size distribution of the finer size fraction $(-0,5 \mathrm{~mm})$ was determined using Horiba LA-950 model laser scattering particle size distribution analyzer (see Fig. 2). The $70 \%$ of the fraction were determined to be below 20 $\mu \mathrm{m}$ in size. The amount of slime $(-20 \mu \mathrm{m})$ in the total run of mine is very significant in equipment selection.

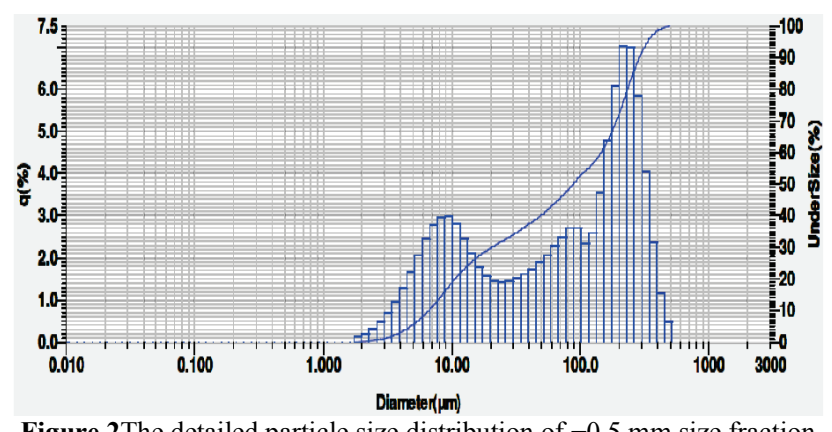

Figure 2The detailed particle size distribution of $-0,5 \mathrm{~mm}$ size fraction of run of mine ore

\section{Experimental Studies and Flowsheet Design}

The samples separated to size fractions were subjected to magnetic separation and the concentrate, middling and tailings were analyzed regarding their $\mathrm{Fe}$ content (in Tab. 1). The analysis revealed that the iron is mainly composed of magnetite and hematite. The parameters applied in magnetic separation were definite however could not be serviced due to company policy.

The design of the separate flowsheets was dependent on those experimental results and proposed for 100 and 130 tons per hour (tph) capacities, and besides the particle size distributions were entered to AggFlow simulation packaged software (see Fig. 3).

The first flowsheet was designed for a capacity of 100 tph (Figure 4). The preliminary studies showed that the size interval of $-80+32 \mathrm{~mm}$ contained $65,72 \% \mathrm{Fe}$ and this fraction could be easily triaged due to physical (color) differences between the concentrate and the tailings. The application of triage was necessary to gain hematite minerals with low magnetic susceptibility. The size fractions applied in the simulation were $-80+30,-30+10$, $-10+0,5$ and $-0,5 \mathrm{~mm}$ due to screen apertures in industrial aspects. The size fractions of $-30+10,-10+0,5$ and $-0,5 \mathrm{~mm}$ were classified by a triple deck screen and a classifier to be fed in magnetic separators. The application of both dry and wet magnetic separators, dewatering screen and sedimentation tank yielded 3 different concentrates with 3 different particle size intervals. The proposed flowsheet for a 100 tph iron ore processing plant would produce $35,2 \mathrm{tph}-30 \mathrm{~mm}$ Fe concentrate, $12 \mathrm{tph}$ $-10+0,5 \mathrm{~mm}$ sized Fe concentrate and 4,1 tph $-0,5 \mathrm{~mm}$ micronized $\mathrm{Fe}$ concentrate. The production of the company with the proposed flowsheet (see Fig. 4) would be a total of 143000 tons Fe concentrate per year (200 days/year (due to harsh weather conditions), 20 hours/day and plant efficiency of $70 \%$ ).

The alternative flowsheet was designed for a capacity of $130 \mathrm{tph}$. In addition, crushing by excavators was bypassed in order to feed $-250 \mathrm{~mm}$ sized particles directly to the plant. In this alternative design, the over size $(+80 \mathrm{~mm})$ particles would be crushed prior to $\log$ washer. This additional circuit would prevent the loss of low grade ore because of triaging middlings and 
moreover, the plant would operate in any weather conditions for the whole year. The increase in the amount of $-30+10 \mathrm{~mm}$ sized concentrate could be observed from the detailed flowsheet (see Fig. 5). Dry screening and dry magnetic separation were eliminated from the system and wet screening and wet magnetic separators were integrated.

Table 1 The metallic Fe content of different size fractions of run of mine

\begin{tabular}{|c|c|c|c|c|c|}
\hline $\begin{array}{l}\text { Size Fraction } \\
(\mathrm{mm})\end{array}$ & $\begin{array}{l}\text { Weight } \\
(\%)\end{array}$ & Product & $\begin{array}{l}\text { Weight (\%) } \\
\text { in Interval }\end{array}$ & $\begin{array}{c}\text { Metallic Fe } \\
\text { Grade (\%) }\end{array}$ & $\begin{array}{c}\text { Recovery }(\%) \\
\text { in Interval }\end{array}$ \\
\hline \multirow{4}{*}{$-80+32$} & \multirow{4}{*}{17,05} & Concentrate & 69,94 & 65,72 & 77,41 \\
\hline & & Middling & 21,10 & 62,93 & 22,36 \\
\hline & & \begin{tabular}{|l} 
Tailing \\
\end{tabular} & 8,96 & 1,51 & 0,23 \\
\hline & & Feed & 100,00 & 59,37 & 100,00 \\
\hline \multirow{4}{*}{$-32+16$} & \multirow{4}{*}{16,89} & Concentrate & 71,69 & 65,57 & 88,31 \\
\hline & & Middling & 10,15 & 55,28 & 10,54 \\
\hline & & Tailing & 18,16 & 3,39 & 1,16 \\
\hline & & Feed & 100,00 & 53,24 & 100,00 \\
\hline \multirow{4}{*}{$-16+8$} & \multirow{4}{*}{7,66} & Concentrate & 67,16 & 62,79 & 95,86 \\
\hline & & Middling & 1,44 & 46,09 & 1,51 \\
\hline & & Tailing & 31,40 & 3,69 & 2,64 \\
\hline & & Feed & 100,00 & 43,99 & 100,00 \\
\hline \multirow{4}{*}{$-8+4,75$} & \multirow{4}{*}{7,74} & Concentrate & 59,75 & 60,91 & 95,46 \\
\hline & & Middling & 0,74 & 54,05 & 1,05 \\
\hline & & Tailing & 39,51 & 3,37 & 3,49 \\
\hline & & Feed & 100,00 & 38,13 & 100,00 \\
\hline \multirow{4}{*}{$-4,75+2$} & \multirow{4}{*}{11,96} & Concentrate & 41,25 & 61,75 & 93,31 \\
\hline & & Middling & 1,02 & 27,63 & 1,03 \\
\hline & & Tailing & 57,73 & 2,68 & 5,66 \\
\hline & & Feed & 100,00 & 27,30 & 100,00 \\
\hline \multirow{4}{*}{$-2+1$} & \multirow{4}{*}{9,54} & Concentrate & 24,65 & 55,05 & 84,72 \\
\hline & & Middling & 4,85 & 26,85 & 8,12 \\
\hline & & Tailing & 70,50 & 2,32 & 7,16 \\
\hline & & Feed & 100,00 & 22,88 & 100,00 \\
\hline \multirow{4}{*}{$-1+0,5$} & \multirow{4}{*}{4,14} & Concentrate & 17,04 & 58,78 & 66,68 \\
\hline & & Middling & 1,60 & 14,82 & 1,58 \\
\hline & & Tailing & 81,36 & 5,86 & 31,74 \\
\hline & & Feed & 100,00 & 15,02 & 100,00 \\
\hline \multirow{4}{*}{$-0,5$} & \multirow{4}{*}{25,03} & Concentrate & 16,50 & 49,88 & 57,84 \\
\hline & & Middling & 0,00 & 0,00 & 0,00 \\
\hline & & Tailing & 83,50 & 7,18 & 42,16 \\
\hline & & Feed & 100,00 & 14,23 & 100,00 \\
\hline Total: & 100,00 & & & 35,07 & \\
\hline
\end{tabular}

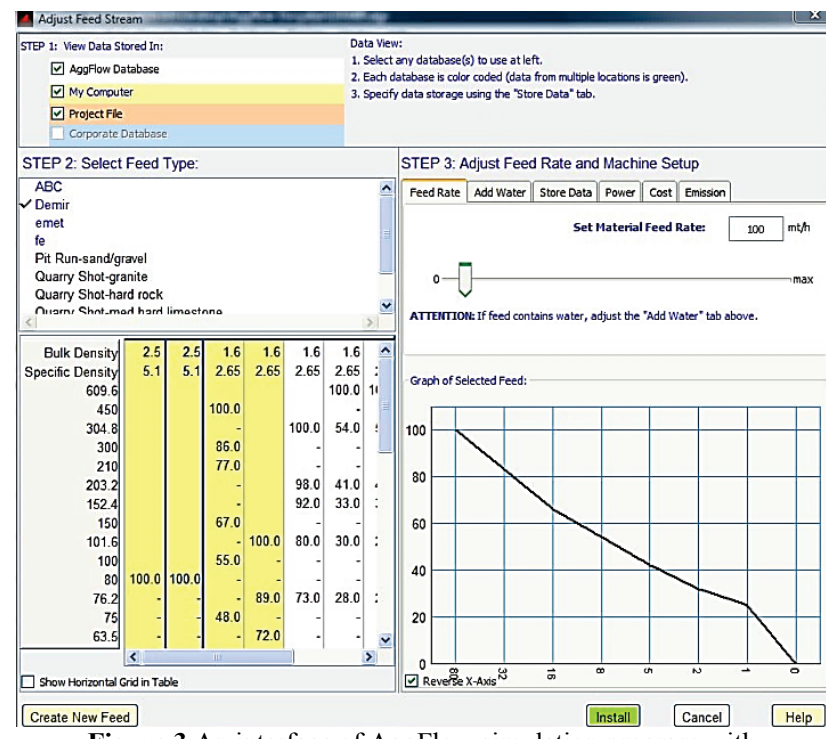

Figure 3 An interface of AggFlow simulation program with specifications and particle size distribution of feed
The proposed flowsheet for a 130 tph iron ore processing plant would produce $41,9 \mathrm{tph}-30+10 \mathrm{~mm}$ Fe concentrate, 7,2 tph $-10+0,5 \mathrm{~mm}$ sized Fe concentrate and 3,5 tph $-0,5 \mathrm{~mm}$ micronized $\mathrm{Fe}$ concentrate. The production of the company with the proposed flowsheet would be a total of 242000 tons Fe concentrate per year (280 days/year, 20 hours/day and plant efficiency of 70 $\%)$. More importantly, the production of valuable and highly demanded size fraction would be increased.

The investigated iron ore processing plant has decided to apply the second flowsheet design (130 tph capacity) and established the plant according to these calculations (see Fig. 6). The plant operates since 2011. 


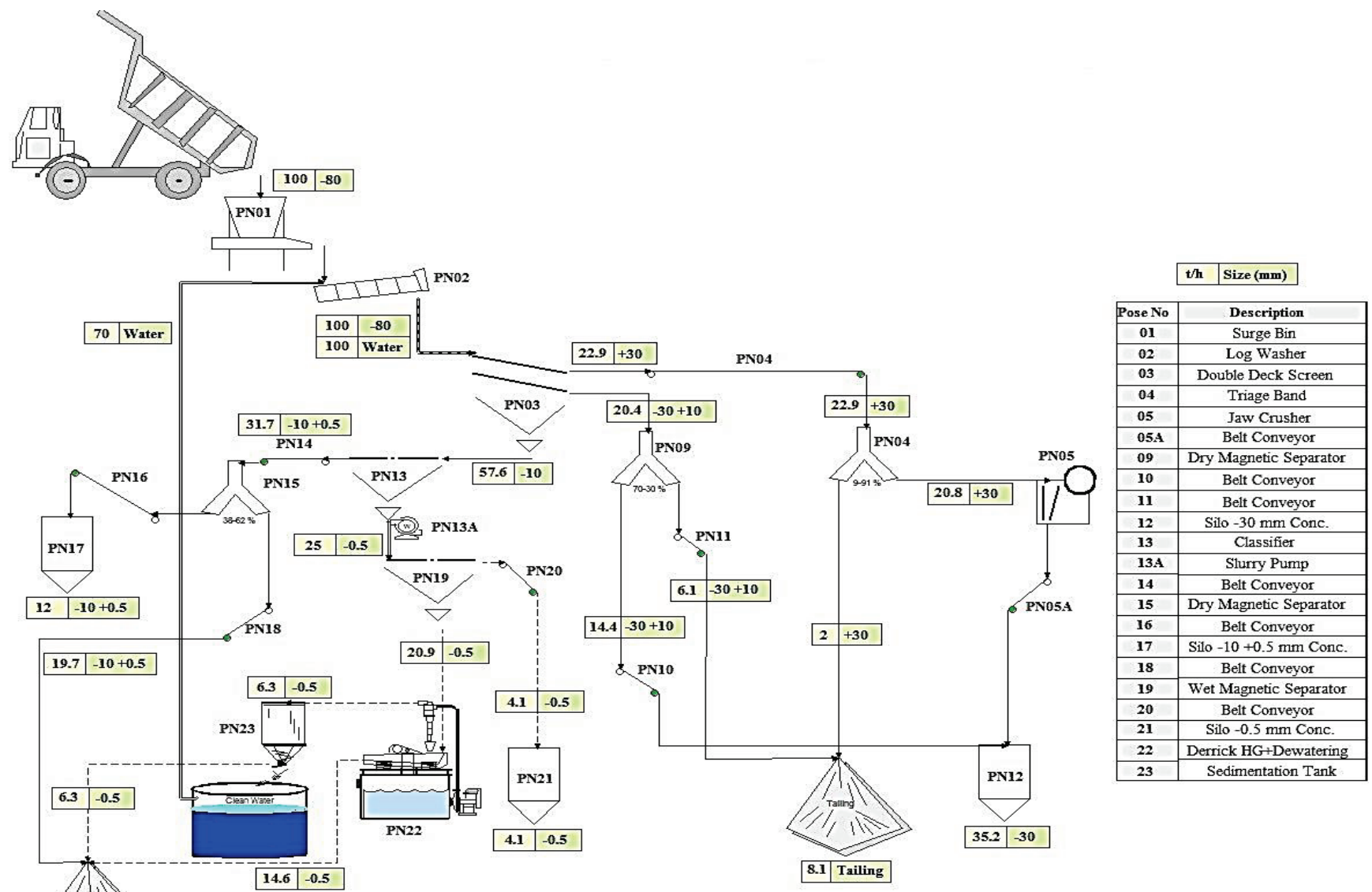

Figure 4 The flowsheet designed and simulated for a capacity of 100 tph iron ore processing

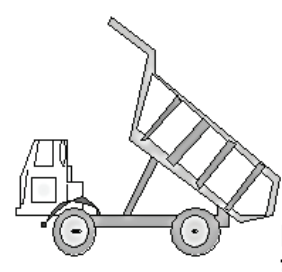

The Suggested Flow Sheet for the New Plant with the Capacity of $130 \mathrm{tph}$
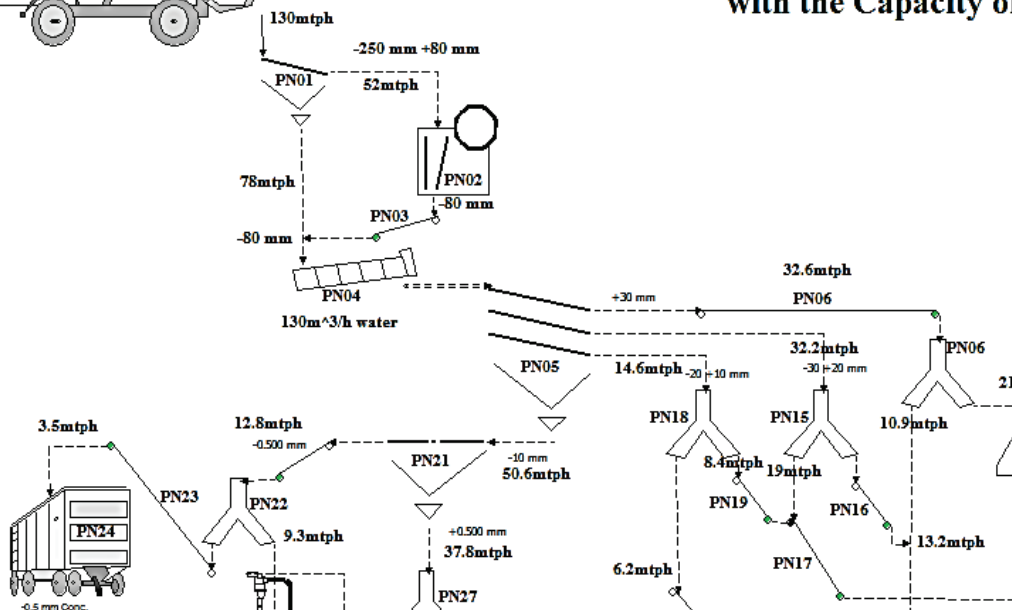

$7 \mathbf{m t p h}$

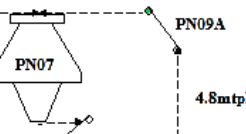

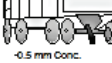

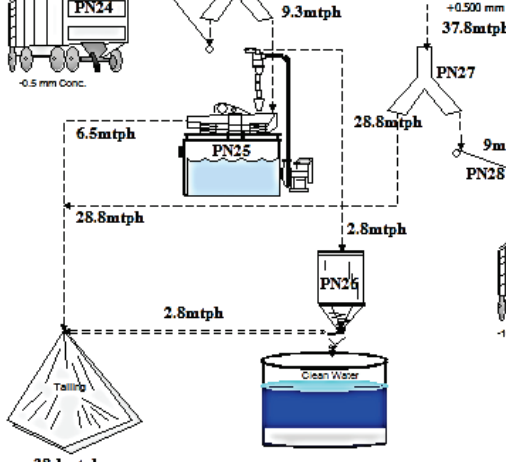

$6.2 \mathrm{mtph} !$

PN17

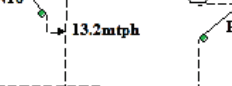

\section{PN08}

N27

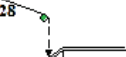

PN20
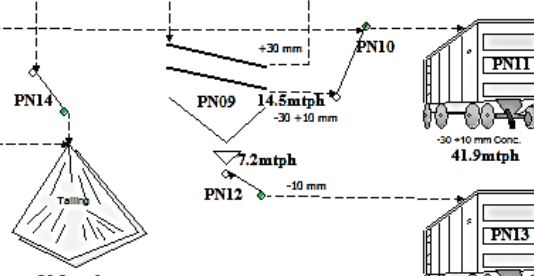

PN12 a- - $10 \mathrm{~mm}$

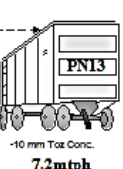

\begin{tabular}{|l|l|}
\hline th & Size (mm) \\
\hline
\end{tabular}

\begin{tabular}{|c|c|}
\hline Pose No & Description \\
\hline 01 & Grill \\
\hline 02 & Jaw Crusher \\
\hline 03 & Belt Conveyor \\
\hline 04 & Log Washer \\
\hline 05 & Triple Deck Screen \\
\hline 06 & Triage Band \\
\hline 07 & Cone Crusher \\
\hline 08 & Belt Conveyor \\
\hline 09 & Double Deck Screen \\
\hline 10 & Belt Conveyor \\
\hline 11 & Silo - -30 +10 mm Conc. \\
\hline $\mathbf{1 2}$ & Belt Conveyor \\
\hline $\mathbf{1 3}$ & Silo-10 mm Conc. \\
\hline $\mathbf{1 4}$ & Tailing Dump \\
\hline $\mathbf{1 5}$ & Wet Magnetic Separator \\
\hline $\mathbf{1 6}$ & Belt Conveyor \\
\hline $\mathbf{1 7}$ & Belt Conveyor \\
\hline $\mathbf{1 8}$ & Wet Magnetic Separator \\
\hline $\mathbf{1 9}$ & Belt Conveyor \\
\hline $\mathbf{2 0}$ & Belt Conveyor \\
\hline $\mathbf{2 1}$ & Classifier \\
\hline $\mathbf{2 2}$ & Wet Magnetic Separator \\
\hline $\mathbf{2 3}$ & Belt Conveyor \\
\hline $\mathbf{2 4}$ & Silo-0.5 mm Conc. \\
\hline $\mathbf{2 5}$ & Derrick HG+Dewatering \\
\hline $\mathbf{2 6}$ & Water Torser \\
\hline $\mathbf{2 7}$ & Wet Magnetic Separator \\
\hline $\mathbf{2 8}$ & Belt Conveyor \\
\hline & \\
& \\
\hline & \\
\hline
\end{tabular}

Figure 5 The designed and simulated flowsheet to process 130 tph iron ore by AggFlow 


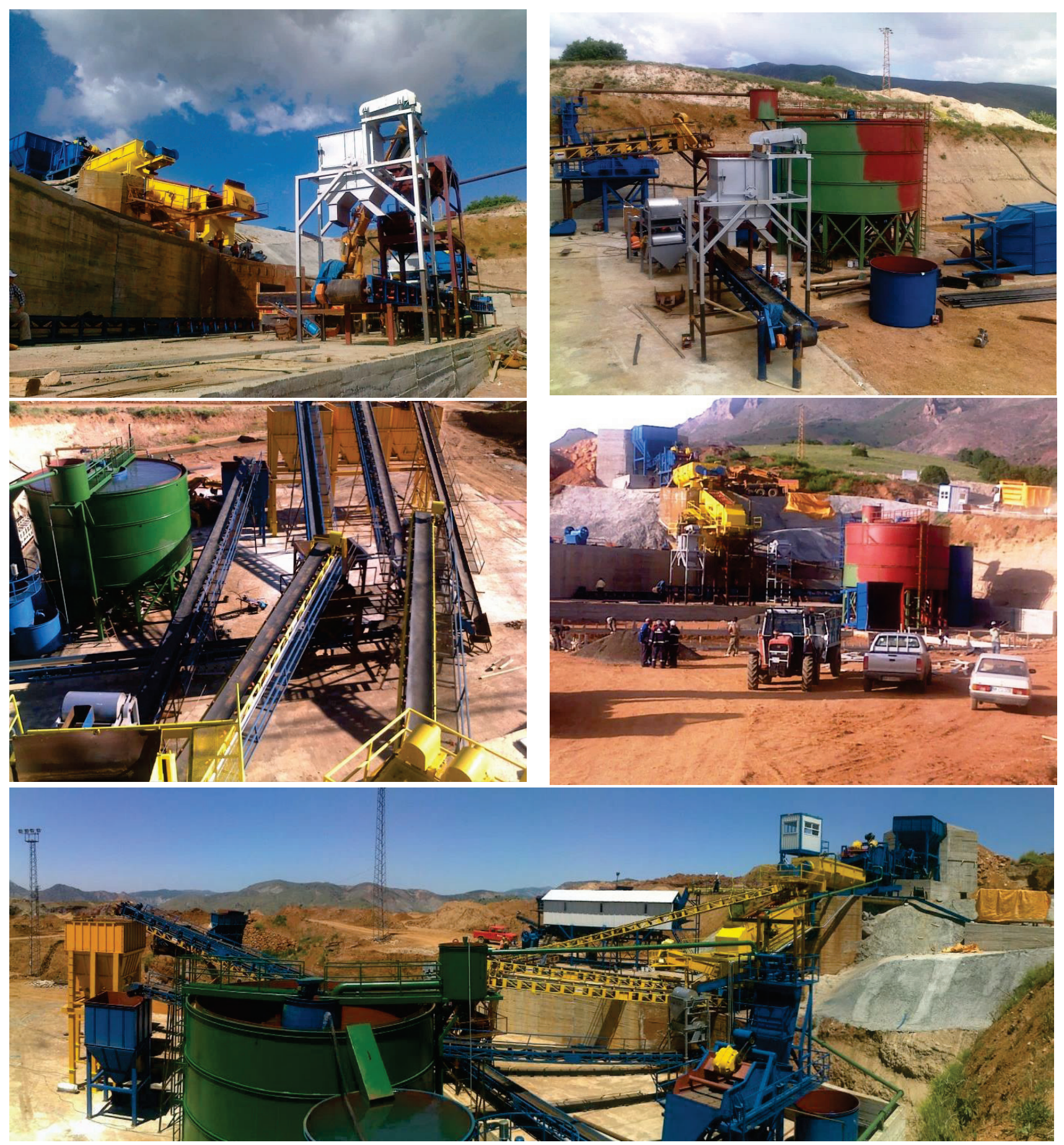

Figure 6 Building stage of the alternative flowsheet with 130 tph capacity in Divrigi-Sivas

\section{Conclusion}

The main aim of this study was to project alternative solutions for an iron ore processing plant regarding different feed rates, weather conditions, different machinery and equipment selection to produce iron concentrates in demanded particle size intervals. The AggFlow simulation packaged program was used to simulate different scenarios and what-if conditions. The optimum machinery and equipment selection was achieved having several alternatives affecting the production capacity and final output of the plant.

Two separate flowsheets with different production capacities were designed and simulated with different machinery selection and arrangements. The first design was to process 100 tph of iron ore, however the harsh weather conditions limited the machinery selection since some dry operations were involved (screening, magnetic separation). As a result of AggFlow simulation application, a total of 143000 tons/year of iron concentrate within the sellable market values was projected to be produced. The alternative flowsheet was designed to overcome the weather conditions and increase the output of the plant. Hence, the capacity of the plant was projected to be $130 \mathrm{tph}$ with operation for the whole year regardless of weather conditions. The crushing, screening and separation units were revised to be operable in wet conditions. Besides, the beneficiation of finer ore $(-0,5 \mathrm{~mm})$ fraction caused an increase in recovery. The total amount of iron concentrate by the alternative design 
would be 242000 tons/year. This second flowsheet was applied and a new iron processing plant was assembled, operating since 2011 in Divrigi - Sivas.

In this study, the former plant design observations, experimental results and simulation software were combined to present an optimum plant design by calculating the final concentrate outputs. Hence, the simulation not only helped in machinery and equipment selection, but also put forth some economic aspects before the assembly of the plant. The importance of simulation was revealed since the company owners were aware of the amount of capital investment, production costs, the machinery to be ordered and most importantly, the amount of concentrate to be produced with different alternatives and applications.

\section{References}

[1] King, R. P. Modeling and Simulation of Mineral Processing Systems. 1st ed. University of Utah, USA, 2001.

[2] Hartge, E. U.; Pogodda, M.; Reimers, C.; Schwier, D.; Gruhn, G.; Werther, J. Flowsheet Simulation of Solids Processes, Technical University Hamburg, Germany, 2006.

[3] Ören, T. Fundamentals of Simulation and Developments. Istanbul, Turkey, 2006. (in Turkish)

[4] Mular, A. L.; Halbe, D. N.; Barrat, D. J. Mineral Processing Plant Design. SME, Littletton, 2002.

[5] Merritt, P. C. Book of Flowsheets, McGraw-Hill, Mining Information Services, 1984

[6] Lync, A. J.; Morrison, R. D. Simulation in Mineral Processing History, Present Status and Possibilities. // Journal of the South African Institute of Min. and Met., 99, 6 (1999), pp. 283-288.

[7] Nikkhah, K.; Anderson, C. Role of Simulation Software in Design and Operation of Metallurgical Plants: A Case Study. // Proceedings of the SME Annual Meeting, Denver, Colorado, 2001

[8] Wills, B. A. Mineral Processing Technology. ButterworthHeinemann, 2006.

[9] Mular, A. L.; Bhappu, R. B. Mineral Processing Plant Design. Society of Mining Engineers of the American Institute of Mining, USA, 1980.

[10] Centeno, M. A. An Introduction to Simulation Modeling. Florida International University, USA, 1996. https://doi.org/10.1145/256562.256564

[11] Yersel, S. E. Increasing the efficiency of Mineral Processing Plants by Simulation. // PhD Thesis, Dokuz Eylül University, Turkey, 2012. (In Turkish)

[12] Deliormanl1, A. H. Marble Processing Plant Design with the Aid of the Computer Simulation. // PhD Thesis, Dokuz Eylül University, Turkey, 2000.

[13] Batar, T.; Tufan, B. Technical Report on Iron Processing Plants in Divrigi-Sivas. // Technical Report, Dokuz Eylül University, Turkey, 2011. (In Turkish)

\section{Authors' addresses}

\section{Baran Tufan}

Department of Mining Engineering,

Dokuz Eylül University,

35390, Izmir, Turkey

baran.tufan@deu.edu.tr 